\title{
WARTOS̃CI DUCHOWE, KULTUROWE I PASTORALNE POSTACI S̃W. KAZIMIERZA DLA DZISIEJSZEGO KATOLICYZMU POLSKIEGO
}

Kiedy zastanawiamy się nad rozmiarami duchowej spuścizny związanej z postacią św. Kazimierza Jagiellończyka, nasuwa się pytanie o jej aktualność po upływie blisko pięciuset lat. Co można ożywić w niej bez popadania w sztuczność lub - co gorsza - w śmieszność? Du sublime au ridicule il n'ya qu'un pas - mówią Francuzi.

Organizatorzy sympozjum wyznaczyli mi rolę reanimatora czy może futurologa pastoralnego. Nie jest to zadanie łatwe, przy jakim takim poczuciu odpowiedzialności, nie jest jednak niemożliwe: dokonał tego np. w stosunku do postaci samego św. Józefa - Gerson. Aktualizacja tego typu jest metodologicznie patrząc - zabiegiem hermeneutycznym, reinterpretacyjnym. Interpretacje pojmowano zawsze jako wydobywanie znaczenia zawartego w tekstach. Jonathan Culler w wydanej ostatnio książce The Pursuit of Signs: Semiotics, Literature, Deconstruction słusznie przypomniał, że interpretacja jest zabiegiem naturalnym, lecz określonym kulturową konwencją. Znaczenie bowiem tkwi w tekście jak jądro w orzechu, lecz ustanawiają je kody i konwencje znane i żywe w określonym środowisku.

Już wcześniej zresztą wiedzieliśmy, że dawne dzieła nabierają nieraz nowych, niekiedy nawet zaskakujących znaczeń. Dotyczyć to może także żywotów postaci historycznych. Pewnej wskazówki może także dostarczyć współczesna biblistyka, która zajmuje się demityzacją, czyli odpakowaniem przesłania zbawczego z obrazów związanych z kręgiem kulturowym, w jakim powstały, a potem zadaniem kerygmatyków staje się wcielenie tych treści w obrazy funkcjonujące współcześnie. Takimi również przesłankami metodycznymi chciałbym się posłużyć przy opracowaniu wyznaczonego mi tematu. Dla ułatwienia, w życiu i działalności św. Kazimierza postanowiłem wyróżnić strefę religijną i świecką.

\section{AKTUALNOSC POSTAW RELIGIJNYCH SW. KAZIMIERZA}

Św. Kazimierz stoi na styku średniowiecza i nowożytności. Jego religijność była bez wątpienia naznaczona duchowością kończącego się średniowiecza i przenikającego coraz bardziej na dwór królewski humanizmu. 
Czytając o praktykach pobożności tego królewskiego syna, nie trudno zauważyć, że ożywia je jeszcze płomień średniowiecznej żarliwości, jednocześnie jest to jednak pobożność nowożytna, pojmowana jako praktykowanie przede wszystkim virtus civilis - obowiązków stanu. Pica della Mirandola, współczesny naszemu Swiętemu, powie w swojej oratio, zatytułowaną później De hominis dignitate, że człowiek nie zdeterminowany przez swoją naturę, jak zwierzęta, może stać się wszystkim w działaniu przez samorealizację. Kazimierz mógłby pod tym względem być typowym bohaterem zaczynającej się nowożytności: młodym, świeckim i ... nie spełnionym. O tym młodym człowieku, który umarł mając 25 lat, można by pisać pod kątem „tysiąca otwartych dróg”, można by napisać jego życiorys pod kątem: kim nie został. Nie został ani królem Węgier, ani Polski. Nie został jednak - i to jest uderzające - patronem pobożnej czy spobożniałej przez rezygnację frustracji politycznej.

Po nieudanej wyprawie na Węgry po koronę (używał już nawet tytułu: Rex Hungariae) nie popadł w rezygnację i zarzucono już pogląd, iż zbrzydły mu sceptr i korona, że odkrył ich marność i odrzucił je na zawsze. Po wyprawie na Węgry Kazimierz bardziej niż przedtem przygotowywał się, by zostać królem polskim. Po roku 1481 przez dwa lata był namiestnikiem ojca w Koronie, rezydując w Radomiu; jego doradcą był Kallimach. Kazimierz okazał się administratorem zaradnym i sprawnym, podkreśla się jego poczucie sprawiedliwości. Dba o bezpieczeństwo i porządek $\mathrm{w}$ kraju, zwalcza rozbójników na pograniczu polsko-śląskim. W latach 1483/4 jest podkanclerzym koronnym. Sprawując te urzędy, odznacza się tolerancją wyznaniową. Ks. Fijałek obalił twierdzenie jakoby Kazimierz wymógł na ojcu dekret zabraniający odbudowy zniszczonych cerkwi i budowy nowych.

Na co szczególnie zwracono uwagę w pobożności św. Kazimierza i jakie może być tego aktualne znaczenie?

1) Kazimierz odznaczał się szczególnym zamiłowaniem do modlitwy. Nie byłoby w tym nic szczególnego, gdyby był on duchownym czy zakonnikiem. Żywoty podkreślają jego modlitwy nocne u wrót kościoła. Dziś, gdy młodzież szuka niekiedy szkoły kontemplacji i modlitwy $w$ buddyzmie, dobrze przypomnieć, że chrześcijaństwo ma własną szkołę modlitwy i wybitne jej wzory, a przecież w końcu XIX i w XX wieku zaczęto widzieć $\mathrm{w}$ świetym Kazimierzu patrona młodzieży, zwłaszcza studiującej. W latach 1895 i 1910 pisał o tym we Lwowie ks. F. Józefowicz.

2) Pobożność Kazimierza była uzewnętrzniana. Jego praktyki religijne przekraczały zwykłe normy. Ani średniowieczny, feudalny, ani renesansowy książę nie modlił się nocą czy nad ranem przed zamkniętym kościołem, jak żebrak czy bigot. Wszyscy biografowie podkreślają, że 
nie jest to topos hagiograficzny. Warto zwrócić uwagę na odwagę Kazimierza w praktykowaniu religii, gdy dzisiaj staje się ono często tak nieformalne, że zupełnie nie uzewnętrzniane. Obywa się ona niekiedy bez chodzenia do kościoła (,w lesie, na łonie natury czuję się bliżej Boga") i jest często przykrywką dla tchórzostwa i oportunizmu. W dobie religijności ułatwianej, po zniżonych kosztach, przykład Kazimierza ukazuje, że wyznawanie wiary wymaga wysiłku i odwagi. Niekonwencjonalne praktyki Świętego powinny zwłaszcza zaapelować do wyobraźni młodzieży.

3) Pobożność maryjna. Odkąd okazało się, że nie był on autorem znalezionego w r. 1604 w jego trumnie pod głową kantyku Omni die, spadło zainteresowanie tym tekstem, choć jest on bardzo ważny dla poznania duchowej biografii Swiętego. Kazimierz kochał ten tekst św. Bernarda, a wybór bywa niekiedy równie ważny, jak inwencja. Warto by na nowo pod tym kątem przeanalizować ten wiersz, przez który nasz Święty wszedł na drogę katolickiej, dobrej, trzeźwej, choć poetycko natchnionej pobożności maryjnej i związał się z nią.

4) Miłosierdzie. Św. Kazimierz był wielkim jałmużnikiem. Może jest to hagiograficzny topos, a może był to locus communis nie pobożnej ówczesnej literatury, tylko ówczesnego pobożnego życia? Faktem jest, że częściej podkreślano miłosierne uczynki księżnych czy królowych, niż królów i książąt. Dziś, gdy rozmiary i wymiary miłosierdzia ukazała nam świeżo encyklika Dives in misericordia, widzimy znaczenie tej cnoty jako miłości wyrażającej się $\mathrm{w}$ działaniu. W przypadku Kazimierza trzeba zwrócić uwagę na dwa momenty: książę - jałmużnik mógłby się mieścić w skali hagiografii średniowiecznej, ale sławią go za to nuncjusz Zaccaria Ferreri i inni biografowie, którzy już są czystej krwi humanistami, a nie są jeszcze ludźmi kontrreformacji, przeżywającymi nostalgię za średniowiecznymi wzorami pobożności; poza tym Kazimierz nie jest ani wrażliwym chłopczykiem, ani starym Kościuszką w Solurze - jest człowiekiem młodym i miłosiernym. Jest to zjawisko, jakie najbardziej wzrusza w Lourdes, gdzie obecnie funkcje brankardierów spełnia przede wszystkim młodzież. Dziś, gdy zapanowała niemal powszechna awersja, fobia, ucieczka przed starzeniem się, chorobami, kalectwem, cierpieniem brzydotą, gdy świat postawił na ołtarzu młodość, owa - jak ją nazwał Gombrowicz - arystokracja biologiczna zstępuje z tronu, by służyć fizycznie czy duchowo zdegradowanym.

5) Czys tość św. Kazimierza, który - wedle świadectwa biskupa Rzeszowskiego - „wolał umrzeć, niż popełnić grzech nieczysty”, nie była brakiem temperamentu. Sądzono, że to $\mathrm{z}$ jego nadmiaru wzięła się jego choroba, albo że wzmaga ją „gorącość krwi”. Nie był chyba mizoginem, bo w r. 1481 nic nie słychać, żeby wzdragał się przed małżeństwem z córką cesarza Fryderyka III. Ks. Rybus sądzi, że dopiero potem złożył 
ślub czystości. Była w Kazimierzu na pewno głęboka awersja do rozpusty, której nie brakło nawet w najbliższym otoczeniu, o czym świadczy pierwsze wydanie Chronica Polonorum Macieja z Miechowa jakie ukazało się w Krakowie w r. 1621; zostało ono z rozkazu Zygmunta Starego skonfiskowane, a następnie wyczyszczone, opuszczając drastyczne informacje. Jego „lepiej umrzeć, niż się skalać” mogło być podszyte wstrętem istoty młodej i czystej. Dwór nie był $\mathrm{w}$ tej dobie przełomu obyczajowego wzorem cnót. Libertynizm niektórych humanistów mógł się tu nakładać na późnośredniowieczne - zauważone przez Huizingę rozluźnienie obyczajów. Sam fakt, że medycyna przepisywała stosunki pozamałżeńskie jako lekarstwo, też jest wymowny. Jeśli Kazimierz uwierzył, że umrze, skoro ich nie posłucha, wówczas jego odmowa nabiera cech heroizmu. Wielka stąd nauka dla naszego stulecia: że Boga trzeba bardziej słuchać niźli ludzi, nawet odzianych w szaty naukowego autorytetu, i że nie należy żyć za wszelką cenę. W tym świetle czystość Kazimierza staje we właściwym osobowościowym kontekście.

Współcześni podkreślali jego silny charakter i roztropność. Sekretarz kancelarii królewskiej, późniejszy biskup przemyski Jan Targowicki napisał: „Książę wzbudzającej podziw cnoty i rozwagi”. Kazimierz nie był więc egzaltowanym młodzieniaszkiem, gdy decydował się na zachowanie czystości kosztem życia. Zasługuje to na uwagę $\mathrm{w}$ dobie permisywiz$\mathrm{mu}, \mathrm{w}$ dobie seksualizmu odpreparowanego przez ducha świata od reszty osobowości, a zwłaszcza od sumienia. Heroizm może więc dotyczyć tego, co sprowadzone zostało do prostej fizjologii, sumienie - przeciwstawić się prymitywnie pojmowanej biologii, a nadprzyrodzoność - swoiście pojmowanej naturalności. Swięty Kazimierz jawi się jako patron takich postaw.

\section{AKTUALNOSC SWIECKA SW. KAZIMIERZA}

W strefie działalności i późniejszego patronatu św. Kazimierza można by wyróżnić dwie dziedziny: polityka i kultura. Strefa profanum w XV stuleciu autonomizuje się zresztą w stosunku do sacrum i ich odróżnienie trwa do dziś. Niemal symbolicznego znaczenia nabiera fakt, że u progu nowożytności w Polsce staje świecki święty.

1) Aktualność społeczno-moralna. Patron Wilna, Patron i obronca Korony i Litwy, sprawujący dla nich owe „cuda interwencyjne", tak popularny u nas, pozostawał przez wieki związany z Litwą. W roku 1907 powstało w Stanach Zjednoczonych litewskie zgromadzenie sióstr od św. Kazimierza; także prowincje amerykańskie litewskich franciszkanów i marianów przybrały jego imię [...] 
W średniowieczu wydzierano sobie świętych patronów. Dość pomyśleć o postaci i relikwiach św. Wojciecha; rywalizacja narodów miała za swój teatr nie tylko ziemię, ale i niebo. Dziś trzeba na to patrzeć inaczej: cóż to za szansa dla przeżycia braterstwa ludów, że istnieją ponad granicami takie mosty, jakimi są święci. Jest to wielka szansa dla nas Polaków, pomawianych niekiedy o nacjonalizm i szowinizm: ukazać z okazji bliskiego jubileuszu kazimierzowskiego, że dzielimy bratersko naszych świętych z bliskimi czy dalszymi narodami.

Postać św. Kazimierza, trzeba by przy tej sposobności przypomnieć Europie, która po przejściu fali zainteresowania jego postacią w XVII stuleciu, zapomniała o nim wkrótce. Wówczas był Kazimierz kimś w rodzaju modelowego chrześcijańskiego „,principe”: Eneasz Silvio Piccolomini zadedykował mu swój traktat, będący swoistym anty-Machiavelem; P. Novelli, zwany Monrealese, malował go koronowanego przez Matkę Boską z Dzieciątkiem do kaplicy Różańca św. w Palermo (obraz ten znajoluje się dziś w tamtejszej Galeria Nazionale); powstawały całe cykle rycin, jak N. Perreya i Ilariona de S. Antonio (Il breve compendio della vita, morte e miracoli del Prencipe Casimiro, Neapol 1629); rytowal go w połowie tego stulecia M. Lauro, a w połowie następnego w Antwerpii - V. G. Bouttats. Rycina spełniała podówczas rolę wzornika i była zawsze świadectwem popularności tematu. Jak daleko jesteśmy od tamtych czasów, skoro słownik ikonograficzny L. Réau (Iconographie des Saints, cz. I, s. 260) myli św. Kazimierza z Janem Kazimierzem (!) Przypomnienie postaci św. Kazimierza także za granicą nie byłoby chyba przedsięwzięciem zbytecznym.

2) Aktualność kulturowa. Uczeń na pewno Długosza, a może i Kallimacha, zaliczany był Kazimierz do najuczeńszych książąt Europy. Byl ,litteratissimus”, co znaczyło wiele w epoce, nad którą świeci humanistyczny ideał ,bonae litterae”. Już jako chłopiec imponował świetnymi mowami łacińskimi. Biskup Jan Targowicki nazywa go „księciem nauki nadzwyczajnej".

Stojąc na granicy między polskim (a zarazem uniwersalistycznym) średniowieczem a włoskim (i wkrótce już polskim) humanizmem, jest Kazimierz jakby emblematyczną postacią naszej kultury tamtego czasu. W jego formacji przecinają się wpływy Zachodu i Wschodu, Południa i Północy. Jest jeszcze człowiekiem średniowiecza i już nowożytności (humaniści zachwycają się nim jako jednym ze swoich). Umieszczony między epokami i ludami, wydaje się Kazimierz jako symbol otwartości kultury polskiej, owej europejskiej róży wiatrów, kultury płodnych pograniczy.

Trudno za samo lubienie Omni die kreować dziś św. Kazimierza na patrona poetów i muzyków. Można by natomiast upatrywać w nim patrona mecenatu kulturalnego Kościoła, wszak wraz z Piotrem z Bnina, 
żołnierzem, humanistą i biskupem skłaniał Kallimacha do opisania dziejów Warneńczyka i losów wyprawy antytureckiej.

Po Vaticanum II, po Gaudium et spes, za pontyfikatu Jana Pawła II doceniamy wreszcie rolę zakorzenienia chrześcijaństwa w kulturze, która naznacza człowieka silniej niż narodowość. Czy nie można by działań Kościoła w Polsce $\mathrm{w}$ domenie kultury związać z patronatem św. Kazimierza? Nie powinno się bowiem poprzestać na zachęcie, by o nim pisano okolicznościowe wiersze i komponowano piosenki. Może św. Kazimierz okazałby się idealnym patronem dla nagród artystycznych Episkopatu lub Rady Kultury przy Episkopacie Polski?

Myśląc o tym przychodzi na pamięć pewna inicjatywa kulturowa związana z Krakowem XVIII wieku. W r. 1785 Józef Salezy Ossoliński pod wpływem i przy współdziałaniu Kołłątaja wystąpił z projektem Galerii Sztuk Wyzwolonych Narodowej w Krakowie. Pod opieką rektora i Akademii miało tu powstać Muzeum Polskie, któremu projektodawca podarował własne zbiory. Radził, by tę galerię podzielić na szkołę obcą i polską (w tym 1785 roku wiedział już o istnieniu sztuki polskiej!); ta ostatnia powinna się dzielić na zbiór dzieł artystów polskich i artystów czynnych w Polsce. Rodzima sztuka rozkwitła jego zdaniem u nas już w XVIII w. Dyrektor galerii, jaka miała się mieścić u św. Barbary w Krakowie, powinien być wybierany spośród artystów-Polaków, a do jego zajęć miało należeć nauczanie młodzieży rysunku i malarstwa. Najlepsze z powstałych dzieł miały zawisnąc $\mathrm{w}$ galerii. W tym programie, będącym wyrazem świadomego swych zadań mecenatu, była też mowa o nagrodach i premiach, które jak pisał Ossoliński, powinny być - tak jak w Rzymie na św. Łukasza - przyznawane w Krakowie w dniu św. Kazimierza. Były więc próby wiązania św. Kazimierza nie tylko z nauką - myślę o nadawaniu jego imienia kolegiom i szkołom - ale i ze sztuką. Czy nie mógłby on patronować jej współcześnie?

Kazimierz - święty z przełomu pierwszego i drugiego pięćsetlecia stoi dziś przed nami jako patron przełomu pierwszego i drugiego tysiąclecia chrześcijaństwa na naszych ziemiach. Każda, a więc i nasza epoka, ma prawo ustalać wokół postaci historycznych nowe, aktualne treści, rozumieć je - w świetle dokumentów - po swojemu. Kallimach żegnał ongiś Kazimierza wspaniałym zdaniem: „Powinien albo się nie urodzić, albo pozostać wiecznym". Skoro jednak się urodził i to dwukrotnie: dla ziemi (dla tej ziemi) i dla nieba, niech nie umiera, niech pozostaje żywy dla nas, dzisiaj. 
LES VALEURS SPIRITUELLES, CULTURELLES ET PASTORALES DE SAINT CASIMIR POUR LE CATHOLICISME POLONAIS CONTEMPORAIN

\section{R és u m é}

Le croquis qui suit cherche à reinterpréter les significations religieuses et laiques de la biographie de saint Casimir. Dans l'esprit du structuralisme et du poststructuralisme nous sommes conscients que chaque époque possède le droit d'établir des contenus propres à elle autour d'un personnage historique. Bien plus dangereux que de tels recours herméneutiques est, semble-t-il, de pénetrer dans la sphère d'une spécifique futurologie pastorale. L'auteur mentionne les traits suivants de la religiosité de saint Casimir: (1) son gôut pour la prière, (2) l'extériorisation de la dévotion et ses formes "difficiles", (3) l'esprit marial, (4) la miséricorde, (5) la chasteté - que l'on doit comprendre dans un contexte particulier adéquat.

L'actualité laique de saint Casimir est d'ordre sociomoral et culturel. Le saint partagé avec les voisins coréligionnaires, surtout lituaniens, pourrait devenir le patron de la petite „Europe familiale”. Déjà Józef Salezy Ossoliński en 1785 liait son patronat au prix artistique des jeunes peintres et dessinateurs. Patron des maintes écoles saint Casimir pourrait figurer le mécenat culturel de l'Église en Pologne. 